\title{
Perbandingan Reaksi Pasar atas Seasoned Equity Offering dengan Tujuan Investasi dan Membayar Utang
}

\author{
Ni Komang Bella Sri Lestari ${ }^{1}$ \\ Fakultas Ekonomi dan Bisnis \\ Universitas Udayana, Indonesia
}

\author{
Dewa Gede Wirama² \\ Fakultas Ekonomi dan Bisnis \\ Universitas Udayana, Indonesia
}

\begin{abstract}
Surel : bellasribuatskripsi@gmail.com
ABSTRAK

Tujuan penelitian ini adalah membandingkan reaksi pasar atas seasoned equity offering (SEO) dengan tujuan investasi dan membayar utang. Penelitian ini dipicu oleh prediksi pecking order theory. Sampel penelitian adalah 62 perusahaan publik Indonesia yang melakukan SEO selama tahun 2013 hingga 2019. Tanggal peristiwa adalah tanggal pengumuman SEO. Jendela peristiwa adalah lima hari di sekitar tanggal pengumuman tersebut. Abnormal return dihitung dengan menggunakan market-adjusted model. Hasil Independent sample t-test menunjukkan bahwa reaksi pasar atas SEO dengan tujuan investasi lebih baik dari reaksi pasar atas SEO dengan tujuan membayar utang. Cumulative abnormal return (CAR) rata-rata $\mathrm{SEO}$ dengan tujuan investasi adalah 0,038 dan untuk membayar utang adalah minus 0,006 . Perbedaan tersebut secara statistis signifikan dengan $p$-value 0,011 . Dengan demikian maka dapat dinyatakan bahwa respon pasar atas penambahan ekuitas, dalam hal ini melalui SEO, tergantung pada tujuan penambahan ekuitas tersebut.
\end{abstract}

Kata Kunci: Seasoned Equity Offering; Reaksi Pasar; Abnormal Return; Market-Adjusted Model.

\section{Comparison Of Market Reactions to Seasoned Equity Offerings with The Purpose Of Investing and Debt Repayment Purpose}

\begin{abstract}
This research compares market reaction to seasoned equity offering (SEO) with investment purpose and debt repayment purpose. The research was triggered by pecking order theory's. The sample of this research is 62 Indonesian public companies that carried out SEO during the 2013 to 2019 period. The SEO announcement date is used as event date. The event window is five days around the event date. Abnormal return is measured by market-adjusted model. The result of independent sample t-test shows that market reaction to SEO with investment purpose is better than market reaction to SEO with debt repayment purpose. Average cumulative abnormal return (CAR) of SEO with investment purpose is 0.038 and for SEO with debt repayment purpose is minus 0.006. The difference is statistically significant ( $p$ value $=0.011$ ). Therefore, it is concluded that markets response to additional equity offering, in this case using SEO, depends on the purpose of the SEO.
\end{abstract}

Keywords: $\quad$ Seasoned Equity Offering; Market Reaction; Abnormal Return; Market-Adjusted Model.

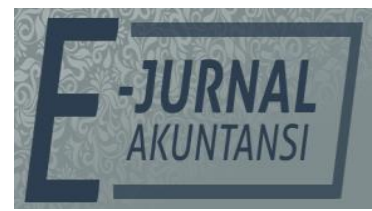

e-ISSN 2302-8556

Vol. 30 No. 10

Denpasar, Oktober 2020

Hal. 2629-2640

DOI:

10.24843/EJA.2020.v30.i10.p15

PENGUTIPAN:

Lestari, N. K. B. S. \&

Wirama, D. G. (2020).

Perbandingan Reaksi Pasar atas Seasoned Equity Offering dengan Tujuan Investasi dan

Membayar Utang. E-Jurnal

Akuntansi, 30(10), 2629-2640

RIWAYAT ARTIKEL:

Artikel Masuk:

4 Juni 2020

Artikel Diterima:

6 Oktober 2020

Artikel dapat diakses : https://ojs.unud.ac.id/index.php/Akuntansi/index 


\section{PENDAHULUAN}

Seasoned Equity Offering (SEO) merupakan penawaran saham tambahan oleh perusahaan yang sudah go public sebagai tambahan atas saham telah ditawarkan kepada masyarakat melalui initial public offering. Tujuan dan motivasi perusahaan yang melakukan SEO adalah memperoleh sumber dana untuk berbagai keperluan, misalnya investasi, memperbaiki struktur modal, meningkatkan likuiditas, meningkatkan nilai perusahaan, dan meningkatkan likuiditas saham dalam penambahan jumlah saham beredar sehingga dapat meningkatkan volume dan frekuensi perdagangan. Kelebihan perusahaan melakukan SEO dibandingkan dengan pinjaman bank atau penerbitan obligasi adalah bahwa perusahaan tidak memiliki kewajiban membayar bunga pinjaman.

SEO dapat dilaksanakan dengan atau tanpa hak memesan efek terlebih dahulu (HMETD). HMETD adalah hak yang terdapat pada saham yang memungkinkan para pemegang saham yang ada untuk membeli efek baru, termasuk saham dan efek yang dapat ditukar menjadi saham dan waran, sebelum ditawarkan kepada publik (Nomor: KEP-26/PM/2003 Keputusan Ketua BAPEPAM Tanggal 17 Juli 2003 tentang Hak Memesan Efek Terlebih Dahulu). Sebagai contoh, PT Astrindo Nusantara Infrastruktur Tbk. (BIPI) melakukan penawaran umum terbatas I dengan HMETD pada tanggal 5 Juli 2019. SEO tanpa hak memesan efek terlebih dahulu merupakan penawaran sekuritas tambahan langsung kepada pihak lain atau publik, tanpa memberi hak istimewa kepada pemegang saham lama (Joshua \& Wibisono, 2014). Konsekuensi SEO tanpa HMETD adalah bahwa pemegang saham lama akan mengalami dilusi atas persentase saham yang dimilikinya. Contoh perusahaan yang melakukan penambahan saham tanpa HMETD adalah PT Merdeka Cooper Gold Tbk. (MDKA) yang melakukan penambahan modal tanpa hak memesan efek terlebih dahulu pada tanggal 18 Juli 2019. Dibatasinya penelitian ini pada perusahaan yang melakukan SEO dengan HMETD. Pembatasan tersebut dilakukan untuk memudahkan pembandingan hasil penelitian ini dengan penelitian sebelumnya mengenai right issue yang telah banyak dilakukan dan peneliti ingin melihat reaksi pemegang saham lama terkait dengan pengumuman hak memesan efek terlebih dahulu yang dilakukan perusahaan untuk mencegah terjadinya penurunan atas persentase kepemilikan sahamnya. Selain itu, sekuritas yang umumnya diperdagangkan di Bursa Efek Indonesia untuk memperoleh dana tambahan adalah dengan mekanisme hak memesan efek terlebih dahulu.

Menurut pecking order theory, penambahan saham baru merupakan alternatif terakhir yang dipilih perusahaan untuk membiayai aktivitas perusahaan. Alternatif pertama adalah menggunakan dana internal, sedangkan alternatif kedua adalah menggunakan dana eksternal berupa utang. Karena merupakan pilihan terakhir, menerbitkan saham baru sering ditafsirkan sebagai sinyal negatif oleh investor sehingga memperoleh respon negatif (Sukwadi, 2006). Namun, hasil riset empiris menunjukkan bahwa tidak semua penawaran saham tambahan memperoleh respon negatif. Dari 20 hasil riset yang sudah ditelusuri, hanya ada tiga yang menunjukkan respon negatif (Sugiana \& Surya, 2013), Kandi \& Parmitasari, 2016) dan (Apsari \& Yasa, 2017), dan satu justru menunjukkan respon positif (Epriyeni \& Kharlina, 2013), sementara 16 sisanya tidak menemukan respon yang secara statistis signifikan. 
Perbedaan respon atas SEO dapat disebabkan oleh perbedaan tujuan SEO tersebut. SEO yang bertujuan investasi kemungkinan akan direspon positif karena memberikan harapan bagi investor mengenai prospek di masa mendatang, sedangkan SEO yang bertujuan membayar utang dapat menyebabkan pasar merespon negatif karena membayar utang dengan menambah ekuitas dianggap sebagai sinyal yang negatif. Sehubungan dengan uraian tersebut sehingga tujuan penelitian ini adalah untuk menguji perbandingan respon pasar atas SEO dengan tujuan investasi dan membayar utang.

Penelitian terdahulu mengenai SEO telah banyak dilakukan diantaranya, Firstiany \& Wirama (2019) menyatakan bahwa pasar tidak merespon pengumuman right issue. Edirisinghe (2015) menyatakan bahwa terdapat respon positif selama 30 hari sebelum pengumuman right issue. (Kusuma \& Suryanawa (2015) menyatakan bahwa terdapat respon pasar negatif sebelum dan sesudah pengumuman right issue, dan selanjutnya disebutkan bahwa pengumuman right issue telah diketahui sebelumnya oleh investor atau telah terjadi kebocoran informasi. Nurmala \& Salmah (2015) menyatakan adanya respon pasar negatif antara sebelum dan sesudah pengumuman right issue. Argawal \& Mohanty (2012) menemukan ikatan yang sangat kuat dan positif tentang abnormal return yang terjadi pada saat pengumuman right issue. Rohit et al., (2016) menemukan adanya AAR yang positif pada hari pengumuman right issue. Miglani (2011) menyatakan bahwa terdapat respon yang signifikan terhadap pengumuman right issue. Berbedanya hasil penelitian sebelumnya membuat peneliti melihat ada sebuah peluang untuk meneliti secara lebih mendalam mengenai SEO yang bertujuan untuk investasi dan membayar utang. Penelitian ini akan dilaksanakan di Bursa Efek Indonesia selama 7 tahun amatan, yaitu 2013 sampai dengan 2019.

Pecking order theory dipopulerkan oleh Myers \& Majluf (1984). Teori tersebut menyatakan bahwa perusahaan memiliki urutan preferensi dalam memilih sumber pendanaan. Menurut pecking order theory, perusahaan lebih menyukai penggunaan dana internal daripada eksternal dalam membiayai pengembangan usahanya. Preferensi pendanaan pertama adalah pendanaan internal yang berasal dari laba ditahan, selanjutnya menggunakan utang dengan menerbitkan obligasi, dan terakhir dengan penambahan ekuitas melalui penerbitan saham. Jadi, penambahan saham baru merupakan pilihan terakhir setelah pilihan pertama dan kedua sudah tidak dapat atau tidak layak untuk dilakukan. Penggunaan dana internal memiliki beberapa keuntungan, di antaranya tidak wajib atau tidak perlu memberikan informasi tentang kondisi keuangan perusahaan, seperti kesempatan investasi yang memiliki kemampuan dan keuntungan yang diharapkan bila kesempatan investasi tersebut diambil, serta tidak memerlukan biaya penerbitan (Noor, 2015). Salah satu alasan digunakannya utang terlebih dahulu dalam penggunaan sumber dana eksternal adalah karena biaya emisi obligasi lebih murah dari biaya emisi saham baru. Investor akan merespon peningkatan utang sebagai suatu kabar baik sedangkan penerbitan saham (penambahan ekuitas) akan direspon sebagai kabar buruk (Dewi \& Wirama, 2017). Investor memandang penerbitan saham baru merupakan sebuah bad news karena terdapatnya asimetri informasi mengenai kondisi perusahaan saat ini dan mengenai prospek perusahaan di masa yang 
akan datang. Akan tetapi, SEO memiliki dua tujuan umum yaitu investasi dan membayar utang. SEO yang bertujuan investasi kemungkinan akan direspon positif karena memberikan harapan bagi investor akan keuntungan di masa yang akan datang. SEO yang bertujuan membayar utang atau melakukan restrukturisasi utang dapat menyebabkan pasar bereaksi negatif karena tindakan tersebut dapat ditafsirkan sebagai ketidakmampuan perusahaan untuk membayar utang dengan menggunakan hasil operasi perusahaan. Investor menangkap keputusan ini sebagai sinyal yang mengenai memburuknya kondisi perusahaan.

Teori pasar efisien menyatakan bahwa pasar sekuritas dikatakan efisien jika harga-harga sekuritas mencerminkan secara penuh informasi yang tersedia Fama (1970). Perubahan harga saham pada pasar efisien mengikuti pola random walk, di mana perkiraan harga saham tidak dapat dilakukan dengan melihat kepada harga historis dari saham tersebut, akan tetapi lebih berdasarkan pada semua informasi yang tersedia dan muncul di pasar. Informasi yang masuk ke pasar dan berikatan dengan suatu sekuritas saham akan mengakibatkan kemungkinan terjadinya pergerakan harga menuju keseimbangan yang baru. Jika pasar merespon dengan cepat dan akurat terhadap suatu informasi yang masuk dan segera membentuk harga keseimbangan yang baru, maka kondisi pasar yang seperti ini yang disebut dengan pasar efisien Hartono (2019). Fama (1970) membagi efisiensi pasar ke dalam tiga bentuk utama, ketiga bentuk pasar efisien ini berhubungan satu dengan yang lainnya. Hubungan ketiga bentuk pasar efisien ini berupa tingkatan yang kumulatif, yaitu bentuk lemah merupakan bagian dari bentuk setengah kuat dan bentuk setengah kuat merupakan bagian dari bentuk kuat. Penelitian ini dilakukan dengan asumsi bahwa pasar modal efisien dalam bentuk setengah kuat. Tiga bentuk utama tersebut diantaranya yaitu pasar efisien dalam bentuk lemah, pasar efisien dalam bentuk setengah kuat, dan pasar efisien dalam bentuk kuat.

Teori kandungan informasi menurut Foster (1986) menjelaskan bahwa kandungan informasi berarti release, berita baru atau pengumuman yang menyebabkan revisi dalam distribusi return sekuritas. Kandungan suatu informasi digunakan untuk menguji apakah suatu peristiwa dapat mempengaruhi keputusan atau kebijakan yang akan diambil. Terdapat tiga faktor yang mempengaruhi kandungan informasi suatu peristiwa atau pengumuman yaitu yang pertama ekspektasi pasar modal terhadap kandungan dan waktu suatu pengumuman. Terdapat ketidakpastian tentang kandungan atau isi maupun waktu dari pengumuman suatu perusahaan. Semakin besar ketidakpastian, maka akan semakin besar potensi suatu pengumuman menyebabkan terjadinya revisi harga-harga sekuritas. Sedangkan yang kedua, implikasi suatu pengumuman terhadap distribusi return sekuritas di waktu yang akan datang, dan yang ketiga adalah Event study dapat digunakan untuk menguji kandungan informasi (information content) dari suatu pengumuman dan dapat juga digunakan untuk menguji efisiensi pasar bentuk setengah kuat. Return salah satu alat untuk mengukur reaksi pasar. Apabila menggunakan abnormal return, maka suatu peristiwa yang memiliki kandungan informasi akan menghasilkan abnormal return kepada pasar dan sebaliknya apabila suatu peristiwa tidak 
memiliki kandungan informasi, maka tidak akan memberikan abnormal return kepada pasar.

SEO merupakan penawaran saham tambahan yang dilakukan perusahaan yang terdaftar di pasar modal, di luar saham yang terlebih dahulu beredar di masyarakat melalui initial public offerings (IPO) (Meggison, 1997) dan (Sulistyanto \& Wibisono, 2013). Selain untuk membiayai kegiatan operasional, penawaran ekuitas ini dilakukan perusahaan untuk mencari tambahan dana yang akan digunakan untuk tambahan investasi atau membayar utang yang jatuh tempo. Alderson \& Betker (1997) dan Traill \& Vos (2001) menyatakan bahwa fenomena pada peristiwa SEO dengan menggunakan konsep windows of opportunity di mana menejelaskan sikap oportunis seorang manajer dengan mengeluarkan ekuitas tambahan pada saat mengetahui bahwa pasar telah menilai perusahaannya terlalu tinggi (overvalued). Padahal dalam jangka Panjang penilaian tersebut tidak bisa dipertahankan karena pasar melakukan koreksi terhadap kesalahannya, yang mengakibatkan harga saham perusahaan akan turun secara signifikan.

Pecking Order Theory menyatakan penerbitan saham tambahan yang dilakukan oleh perusahaan dianggap sebagai sinyal yang bersifat bad news, karena terdapat asimetris informasi mengenai kondisi perusahaan pada saat ini dan juga prospek perusahaan di masa yang akan datang hanya dimiliki oleh salah satu pihak yaitu manajemen perusahaan. Pecking Order Theory menyatakan bahwa perusahaan lebih menyukai penggunaan dana internal daripada eksternal dalam membiayai pengembangan usahanya. Pecking Order Theory menyarankan perusahaan memiliki preferensi dalam memilih sumber pendanaan dengan mempertimbangkan biaya termurah dan risiko paling kecil. SEO dengan tujuan investasi membuat investor lebih tertarik menggunakan haknya untuk membeli saham, dibandingkan dengan tujuan membayar utang. Perusahaan yang melakukan SEO dengan tujuan investasi dapat meningkatkan keuntungan di masa yang akan datang. Sedangkan tujuan membayar utang dapat menyebabkan investor tidak ingin menggunakan haknya untuk membeli saham baru tersebut, karena membayar utang dianggap tidak menghasilkan pendapatan di masa mendatang.

Yusuf \& Susanto (2009) menyatakan bahwa terdapat perbedaan rata-rata abnormal return sebelum dan sesudah pengumuman right issue karena pemegang saham lama berasumsi bahwa dengan right issue tersebut perusahaan akan beroperasi lebih baik dari sebelumnya. Medeiros (2015) dan Kithinji (2014) menyatakan bahwa terdapat perbedaan abnormal return sebelum dan sesudah right issue karena dianggap bahwa pengumuman right issue tersebut merupakan informasi yang positif bagi pemegang saham lama. Kendirli \& Elmali (2016) menyatakan bahwa terdapat reaksi negatif selama 10 hari setelah tanggal pengumuman right issue. Penelitian Apsari \& Yasa (2017) menyatakan bahwa terdapat reaksi pasar negatif sebelum pengumuman right issue, dikarenakan adanya kebocoran informasi pada perusahaan yang akan melakukan pengumuman right issue. Ogada \& Kalunda (2017) menyatakan bahwa pengumuman right issue direaksi signifikan lebih tinggi pada saat setelah pengumuman. Berdasarkan teori dan penelitian terdahulu, sehingga hipotesis penelitian ini adalah sebagai berikut. 
Ha: Reaksi pasar pada perusahaan yang melakukan SEO dengan tujuan investasi lebih baik dari reaksi pasar pada perusahaan yang melakukan SEO dengan tujuan membayar utang.

\section{METODE PENELITIAN}

Pendekatan yang digunakan dalam penelitian ini termasuk ke dalam kategori event study atau studi peristiwa. Studi peristiwa merupakan analisis empiris yang digunakan untuk menguji ada-tidaknya kandungan informasi pada suatu peristiwa. Dalam hal ini, informasi adalah sesuatu yang mempengaruhi nilai perusahaan. Kandungan informasi tercermin dari ada-tidaknya respon pasar atas peristiwa yang bersangkutan. Respon pasar tersebut diukur dengan abnormal return.

Tanggal peristiwa (event date) yang digunakan adalah tanggal diumumkannya SEO. Tanggal tersebut diakses dari situs www.britama.com, sebuah situs yang secara rutin mengumumkan aksi korporasi emiten Indonesia. Jendela peristiwa (event window) adalah lima hari di sekitar tanggal peristiwa, yaitu 2 hari sebelum pengumuman, 1 hari pada saat pengumuman, dan 2 hari setelah pengumuman dilakukan. Periode sebelum tanggal pengumuman diperhitungkan untuk mengantisipasi kebocoran informasi, sedangkan periode setelah pengumuman diperhitungkan untuk mengantisipasi kelambatan pasar dalam bereaksi atas suatu peristiwa. Respon pasar diukur dengan cumulative abnormal return (CAR) selama lima hari jendela peristiwa dengan menggunakan market-adjusted model. Data harga saham menggunakan adjusted closing price pada situs www.finance.yahoo.com. Berikut ini adalah tapahan penghitungan CAR.

Return realisasian adalah return yang sebenarnya terjadi, yang dihitung dengan rumus berikut (Hartono, 2019: 668).

$$
R_{i, t}=\frac{P_{i, t}-P_{i, t-1}}{P_{i, t-1}}
$$

Keterangan:

$\mathrm{Ri}, \mathrm{t}=$ Return realisasian sekuritas ke-i pada periode ke-t.

$\mathrm{Pi}, \mathrm{t} \quad=$ Harga penutupan hari ke-t.

Pi,t-1 = Harga penutupan hari ke-t-1 (hari bursa sebelumnya).

Return ekspektasian adalah return yang diprediksi akan terjadi. Rumus

return ekspektasian dengan market-adjusted model adalah sebagai berikut (Hartono, 2019: 428).

$$
E R_{i, t}=\frac{I H S G_{t}-I H S G_{t-1}}{I H S G_{t}}
$$

Keterangan:

$\mathrm{ERi}, \mathrm{t} \quad=$ Return ekspektasian periode $\mathrm{t}$.

IHSGt = Indeks Harga Saham Gabungan penutupan pada hari ke-t.

IHSGt-1 = Indeks Harga Saham Gabungan penutupan pada hari ke t-1.

Abnormal return adalah selisih return realisasian dan return ekspektasian. Abnormal return dihitung dengan rumus sebagai berikut (Hartono, 2019: 668).

$A R_{i, t}=R_{i, t}-E R_{i, t}$ 
Keterangan:

$\mathrm{ARi}, \mathrm{t}=$ Abnormal return sekuritas ke-i pada periode ke-t.

$\mathrm{Ri}, \mathrm{t} \quad=$ return realisasian untuk sekuritas ke-i pada periode ke-t.

$\mathrm{E}[\mathrm{Ri}, \mathrm{t}]=$ Return ekspetasian sekuritas ke-i untuk periode ke-t.

CAR adalah penjumlahan abnormal return selama jendela peristiwa. Pemilihan singkatan CAR dari Bahasa Inggris cumulative abnormal return, dan bukan RAK dari Bahasa Indonesia return abnormal kumulatif dilakukan karena istilah tersebut telah sangat dikenal dalam studi peristiwa. CAR dihitung dengan rumus sebagai berikut (Hartono, 2015: 683).

$C A R=\sum_{t}^{T} A R_{i, t}$

Keterangan:

CAR = AR sekuritas dari periode $t$ sampai $\mathrm{T}$.

Sampel penelitian adalah perusahaan yang melakukan SEO dengan HMETD selama tahun 2013 sampai 2019. Perusahaan dikeluarkan dari sampel jika melakukan aksi korporasi lain dalam jendela peristiwa. Hipotesis diuji dengan independent sample t-test, yang membandingkan CAR pada kelompok sampel perusahaan yang melakukan SEO dengan tujuan investasi dan kelompok sampel perusahaan yang melakukan SEO dengan tujuan membayar utang. Independent sample t-test adalah uji komparatif atau uji beda untuk menentukan apakah dua sampel yang tidak berhubungan memiliki rata-rata yang berbeda. Kriteria independent samples t-test ini yaitu apabila asymp. sig. (2-tailed) $\leq 0,05$ maka hipotesis penelitian dinyatakan diterima.

\section{HASIL DAN PEMBAHASAN}

Sampel penelitian adalah perusahaan yang melakukan SEO dengan HMETD yang bertujuan investasi atau membayar utang yang terdaftar di Bursa Efek Indonesia periode 2013-2019. Sampel akhir terdiri atas 62 perusahaan. Berikut ini adalah hasil proses penyaringan sampel.

\section{Tabel 1. Hasil Seleksi Sampel}

\begin{tabular}{llc}
\hline No & \multicolumn{1}{c}{ Keterangan } & Jumlah \\
\hline 1 & Perusahaan yang melakukan SEO mekanisme right issue dengan & 77 \\
& tujuan investasi dan membayar utang pada tahun 2013-2019 & \\
2 & Perusahaan yang melakukan aksi korporasi lain & 10 \\
3 & Perusahaan yang terpilih sebagai sampel & 67 \\
4 & Amatan yang teridentifikasi sebagai outlier & $(5)$ \\
& & Jumlah sampel yang digunakan \\
\hline
\end{tabular}

Sumber: Data Penelitian, 2020

Pada Perusahaan yang melakukan SEO mekanisme right issue dengan tujuan investasi dan membayar utang pada tahun 2013-2019 berjumlah 77 perusahaan diantaranya 56 perusahan yang melakukan SEO dengan tujuan investasi dan yang bertujuan membayar utang berjumlah 21 perusahaan. Setelah melakukan indentifikasi dengan metode penentuan sampel yang digunakan adalah nonprobability sampling dengan teknik purposive sampling maka SEO yang bertujuan investasi berjumlah 50 perusahaan, sedangkan yang bertujuan membayar utang berjumlah 17 perusahaan. Hasil indentifikasi menemukan bahwa dari 67 sampel perusahaan ditemukan adanya 5 sampel perusahaan yang 
tergolong outlier. Outlier merupakan data yang memiliki karakteristik unik yang muncul dalam bentuk nilai ekstrim baik untuk sebuah variabel tunggal atau variabel kombinasi (Ghozali, 2016). Outlier diindentifikasi dengan cara menganalisis sebaran data penelitian dengan melihat scatter plot. Dengan demikian, total perusahaan dalam sampel yang dianalisis pada penelitian ini adalah sebanyak 62 perusahaan. Cara membedakan tujuan investasi dan tujuan membayar utang pada penelitian ini yaitu terlebih dahulu mencari tujuan dari SEO dengan mekanisme hak memesan efek terlebih dahulu pada website www.britama.com. Setelah mengetahui tujuannya baru dimasukkan kedalam kategori yang bertujuan investasi atau bertujuan membayar utang.

Tabel 2, menyajikan statistik deskriptif, statistik deskriptif dalam penelitian ini bertujuan untuk memberikan gambaran atau deskriptif suatu data yang dilihat dari nilai minimum, maksimum, rata-rata, dan standar deviasi. Statistik deskriptif berhubungan dengan pengumpulan dan peringkat data yang menggambarkan karakteristik sampel yang digunakan dalam penelitian. Analisis ini berguna untuk menjelaskan karakteristik sampel terutama mencangkup nilai rata-rata (mean). Hasil statistik deskriptif yang menunjukkan SEO dengan tujuan investasi memiliki CAR dengan nilai minimum -0,061, maksimum 0,242, dan rata-rata 0,038 dengan deviasi standar 0,065. SEO dengan tujuan membayar utang memiliki CAR minimum -0,055, maksimum 0,084, dan rata-rata -0,006 dengan deviasi standar sebesar 0,035. Nilai CAR rata-rata untuk sampel secara keseluruhan adalah 0,026 dengan deviasi standar 0,061.

Tabel 2. Statistik Deskripif Variabel Penelitian

\begin{tabular}{lccccc}
\hline \multicolumn{1}{c}{ Variabel } & N & Minimum & Maksimum & $\begin{array}{c}\text { Rata- } \\
\text { rata }\end{array}$ & $\begin{array}{c}\text { Deviasi } \\
\text { Standar }\end{array}$ \\
\hline CAR Investasi & 45 & $-0,061$ & 0,242 & 0,038 & 0,065 \\
CAR Membayar Utang & 17 & $-0,055$ & 0,084 & $-0,006$ & 0,035 \\
CAR SEO keseluruhan & 62 & $-0,061$ & 0,242 & 0,026 & 0,061 \\
sampel & & & & &
\end{tabular}

Sumber: Data Penelitian, 2020

Sebelum melakukan independent sample t-test, terlebih daluhu dilakukan uji homogenitas varians dengan Levene's Test. Uji homogenitas varians digunakan untuk menguji sama-tidaknya varians pada dua atau lebih distribusi (Sugiyono, 2017). Dasar pengambilan keputusan untuk uji homogenitas varians yaitu jika nilai signifikansi $>0,05$ maka disimpulkan bahwa varians sama secara signifikan (homogen), sebaliknya jika nilai signifikansi $\leq 0,05$ maka disimpulkan bahwa varian berbeda secara signifikan (tidak homogen). Tabel 3 menunjukkan hasil uji homogenitas varians tersebut. Nilai Levene's ditunjukkan pada baris nilai Based on mean, yaitu 3,716 dengan tingkat signifikansi sebesar 0,059. Hal tersebut berarti bahwa asumsi homogenitas varians terpenuhi.

Tabel 3. Hasil Uji Homogenitas Varians

\begin{tabular}{ccccc}
\hline & & Levene Statistic & Sig. & Keterangan \\
\hline CAR & Based on mean & 3,716 & 0,059 & Homogen \\
\hline
\end{tabular}

Sumber: Data Penelitian, 2020

Pengujian hipotesis dilakukan dengan independent sample t-test. Independent sample t-test adalah jenis uji statistika yang bertujuan untuk membandingkan rata-rata dua grup yang tidak saling berkaitan. Dalam 
penelitian ini menggunakan independent sample t-test untuk mengindentikasi perbandingan respon pasar atas SEO dengan tujuan investasi dan membayar utang. Tabel 4 menunjukkan nilai t-hitung sebesar 2,617 dengan nilai signifikansi 0,011, yang lebih kecil dari tingkat signifikasi yang ditentukan yaitu 0,05. Dengan demikian, dapat disimpulkan bahwa ada perbedaan yang signifikan antara ratarata nilai CAR pada SEO dengan tujuan investasi dengan SOE dengan tujuan membayar utang. Berdasarkan hasil tersebut maka hipotesis penelitian dinyatakan diterima, yaitu respon pasar pada perusahaan yang melakukan SEO dengan tujuan investasi lebih baik dari respon pasar pada perusahaan yang melakukan SEO dengan tujuan membayar utang (lihat juga Tabel 2).

Tabel 4. Hasil Independent Sample t-Test

\begin{tabular}{cccccc}
\hline & & $\mathrm{t}$ & $\mathrm{df}$ & Sig. (2-tailed) & Keterangan \\
\hline $\mathrm{CAR}$ & Equal variances assumed & 2,617 & 60 & 0,011 & Signifikan \\
\hline
\end{tabular}

Sumber: Data Penelitian, 2020

Hasil penelitian ini menunjukkan bahwa terdapat respon pasar positif pada perusahaan yang melakukan SEO dengan tujuan investasi dan negatif pada perusahaan yang melakukan SEO dengan tujuan membayar utang. Berdasarkan pengujian hipotesis yang telah dilakukan melalui uji Independent sample t-test, didapat nilai signifikansi sebesar 0,011 yang artinya ada perbedaan CAR untuk kelompok sampel signifikan dan hasil analisis statistik deskriptif bahwa nilai rata-rata pada CAR yang bertujuan investasi lebih tinggi sebesar 0,038 dibandingkan CAR yang bertujuan membayar utang sebesar -0,006. Hasil ini sesuai dengan hipotesis dan menunjukan bahwa pasar bereaksi lebih baik terhadap SEO yang bertujuan investasi dibandingkan dengan yang bertujuan membayar utang. Hasil pengujian tersebut mengindikasikan bahwa investor pasar modal memberikan tanggapan yang berbeda terhadap penawaran saham baru tersebut. Penerbitan saham tambahan mendapat respon yang baik jika dana yang diperoleh diinvestasikan untuk proyek terutama yang menjanjikan return yang tinggi, baik itu proyek investasi baru atau peningkatan modal kerja (Sukwadi, 2006). Investor memiliki pandangan bahwa tujuan penggunaan dana untuk investasi menjanjikan keuntungan di masa mendatang.

Temuan dari penelitian terdahulu yang sesuai dengan tujuan investasi yang direspon positif diantaranya oleh Kandi \& Parmitasari (2014) menyatakan bahwa terdapat perbedaan yang signifikan antara return saham sebelum dan sesudah pengumuman right issue. Sedangkan penelitian yang sesuai dengan tujuan membayar utang yang direspon negatif diantaranya Amir \& Suaryana (2019) menyatakan bahwa tidak ada reaksi pasar terhadap pengumuman right issue, yang berarti pengumuman right issue tidak memiliki kandungan informasi sehingga tidak mempengaruhi investor mengambil keputusan. Yakup \& Cahyadi (2016) menyatakan bahwa right issue memiliki efek negatif dan tidak signifikan terhadap perusahaan yang terdaftar di BEI.

\section{SIMPULAN}

Berdasarkan hasil analisis dan pembahasan yang telah dipaparkan sebelumnya dapat disimpulkan bahwa reaksi pasar pada perusahaan yang melakukan SEO dengan tujuan investasi lebih baik dari respon pasar pada perusahaan yang 
melakukan SEO dengan tujuan membayar utang. Hal tersebut dapat dilihat dari hasil pengujian hipotesis menggunakan independent sampel t-test yang menunjukkan nilai rata-rata CAR pada tujuan investasi sebesar 0,038, sedangkan pada tujuan membayar utang sebesar $-0,006$. Perbedaan tersebut secara statistis signifikan. Dengan demikian dapat dikatakan bahwa tujuan SEO memiliki kandungan informasi dan memengaruhi investor dalam mengambil keputusan di pasar modal Indonesia.

Investor yang bermaksud menambah investasi pada perusahaan yang melakukan SEO disarankan untuk mempertimbangkan tujuan dari dilakukannya SEO tersebut. Penelitian selanjutnya dapat mempertimbangkan faktor lain sehubungan dengan SEO yang berpotensi direspon secara berbeda oleh pasar.

\section{REFERENSI}

Amir, P. Q., \& Suaryana, I. G. N. A. (2019). Reaksi Pasar Modal Terhadap Pengumuman Right Issue Pada Perusahaan yan Terdaftar Di Bursa Efek Indonesia. E-Jurnal Akuntansi Universitas Udayana, 28(1), 159-187.

Apsari, I. A. W. P., \& Yasa, G. W. (2017). Analisis Reaksi Pasar Terhadap Pengumuman Right Issue Pada Perusahaan Go Public yang Tercatat Di BEI. E-Jurnal Akuntansi Universitas Udayana, 18(2), 1343-1368.

Argawal, A., \& Mohanty, P. (2012). The Impact of Right Issue on Stock Returns In India. Asia Pasific Finance and Accunting Review, 1(1), 5-16.

Dewi, P. S. M. Y., \& Wirama, D. G. (2017). Pecking Order Theory: Pengaruh Profitabilitas dan Pertumbuhan Perusahaan Pada Keputusan Pendanaan Perusahaan. E-Jurnal Akuntansi Universitas Udayana, 18(3), 2423-2450.

Edirisinghe, C. (2015). Stock Price Reaction to Announcements of Right Issues and Debenture Issues: Evidence from Colombo Stock Exchange Stock Price Reaction to Announcements of Right Issues and Debenture Issues : Evidence from Colombo Stock Exchange. International Journal of Business and Soscial Research, 5(2), 67-77.

Epriyeni, A., \& Kharlina, R. (2013). Pengaruh Pengumuman Merger, Akuisisi dan Right Issue Terhadap Abnormal Return Saham Di Bursa Efek Indonesia. Jurnal Ekonomi, 1(1), 1-7.

Fama, E. F. (1970). Efficient Capital Market; A review of Theory and Empirical Work. The Journal of Finance, 25(2), 383-417.

Firstiany, J. I., \& Wirama, D. G. (2019). Reaksi Pasar atas Right Issue. E-Jurnal Akuntansi Universitas Udayana, 27(1), 285-310.

Foster, G. (1986). Financial Statement Analysis. Second Edition, Singapore: prenticehall, 2(2), 432-450.

Ghozali, H. I. (2016). Aplikasi Analisis Multivariate dengan Program IBM SPSS 23. (Edisi Kedelapan). Semarang: Badan Penerbitan Universitas Diponogoro.

Joshua, B., \& Wibisono, C. H. (2014). Perbedaan Kinerja Perusahaan Sebelum dan Sesudah Seasoned Equity Offerings. Jurnal Manajemen Fakultas Ekonomi. Universitas Atma Jaya Yogyakarta, 1-14.

Kandi, R., \& Parmitasari, R. D. A. (2014). Analisis Return Saham Sebelum dan Sesudah pengumuman Right Issue pada Perusahaan Perbankan yang Terdaftar Di Bursa Efek Indonesia Tahun 2010-2014. Jurnal Manajemen Dan Bisnis Islam Allauddin, 1(1), 1-15. 
Kendirli, S., \& Elmali, M. E. (2016). The Effects of Right Offering Announcements on Returns of Shares of Deposit Banks Traded in Istanbul Stock-Exchange. Journal of Economic Development, Environment and People, 5(1), 74-82.

Kithinji, J. G., Oluochh, W., \& Mugo, R. (2014). What is The of Right Issue on Firm Share Performance in The Nairobi Securities Exchange. Research Journal of Finance and Accounting, 5(4),76-84.

Kusuma, P. A. J., \& Suryanawa, I. K. (2015). Analisis Komperatif Kinerja Saham Sebelum dan Sesudah Pengumuman Right Issue. E-Jurnal Akuntansi Universitas Udayana, 12(3), 566-581.

Medeiros, O., \& Matsumoto, A. (2005). Brazilian Market Reaction tp Equity Issue Announcements. Revista de Administracao, Review, 2(2), 35-46.

Meggison, W, L. (1997). CorporateFinance Theory. Addison-Wesley Aducational Publisher Inc, 40(3), 201-216.

Miglani, P. (2011). An Empirical Analysis Of Impact Of Right Issue On Shareholders Returns Of Indian Listed Companies. Journal of Arts, Science $\mathcal{E}$ Commerce, II(4), 169-176.

Myers, S. C., \& Majluf, N. S. (1984). Coorporate Financing and Investment Decisions When Firm Have Information that Investor do not Have. Journal of Financial Economic, 13(1), 187-221.

Noor, T. (2015). Pengujian Pecking Order Theory dan Analisis Pengaruh Karakteristik Perusahaan Terhadap Struktur Modal Emiten Sektor Pertanian. Fakultas Manajemen Dan Bisnis Institut Pertanian Bogor, Bogor., 1(1).

Nurmala, \& Salmah, N. N. A. (2015). Reaksi Pasar Terhadap pengumuman Right Issue Di Bursa Efek Indonesia. Jurnal Manajemen Dan Bisnis Sriwijaya, 13(3), 332-342.

Ogada, A., \& Kalunda, E. (2017). Impact of Rights Issue on Share Returns of Firms Listed on The Nairobi Securities Exchange, Kenya. IOSR Journal of Business and Management, 19(8), 54-62.

Rohit, B., Pinto, P., \& Bolar, S. (2016). Impact of Stock Splits and Rights Issue Announcements on Market Price: Evidence From India. A Management Journal, 7(2), 1-13.

Sugiana, B., \& Surya, B. A. (2013). Implication Of Right Issue Cum And Ex-Date Announcement To The Stock Return ( Empirical Study On Indonesia Stock Exchange Period: 2009-2012 ). The Indonesia Journal Of Business Administration, 2(12), 1395-1410.

Sugiyono. (2017). Metode penelitian Pendekatan Kuantitatif, Kualitatif, Kombinasi, RED dan Penelitian Evaluasi. Bandung: CV Alfabeta.

Sukwadi, R. (2006). Analisis Perbedaan Kinerja Keuangan Perusahaan yang Melakukan Right Issue dan Perusahaan yang Tidak Melakukan Right Issue Di Bursa Efek Jakarta Periode 2000-2003. Journal Management, 1(1), 1-35.

Sulistyanto, H. S., \& Wibisono, H. (2013). Seasoned Equity Offerings: Antara Agency Theory, Windows of Oportunity dan Penurunan Kinerja. Simposium Nasional Akuntansi, VI Oktober, 131-140.

Traill, M., \& Ed Vos. (2001). Do Seasoned Equity Offerings Really Underperform in the Long Run? Evidence from New Zealand. Working Paper, 1(1), 1-16.

Yakup, W. Y., \& Cahyadi, Y. (2016). Analysis Of Right Issue Announcement Effect Toward Stock Price Movement and Stock Trading Volume Within 
Issuer In Indonesia Stock Exchange. Binus Business Review, 7(1), 33-38.

Yusuf, S. D., Djazuli, A., \& Susanto, H. . H. (2009). Analisis Reaksi Investor Terhadap Pengumuman Right Issue Di Bursa Efek Jakarta. Jurnal Wacana, 12(4), 792-814. 